\title{
Human Anti-Human Minibody Antibody
}

National Cancer Institute

\section{Source}

National Cancer Institute. Human Anti-Human Minibody Antibody. NCI Thesaurus. Code C123803.

Human antibodies which recognize humanized minibodies. These can develop in response to treatment with therapeutic minibodies and may limit the effectiveness of the treatment. 